\title{
SEMANTIC APPROACHES IN ISLAMIC STUDIES; EFFORTS TO UNDERSTAND TEXT THROUGH MEANING
}

\author{
Rasmuin', \& Amin Maghfuri² \\ ${ }^{1}$ UIN Maulana Malik Ibrahim Malang, ${ }^{2}$ UIN Sunan Kalijaga Yogyakarta \\ 1 muin@uin-malang.ac.id, 2aminmaghfuri@yahoo.com \\ DOI: $h t t p: / / d x$.doi.org/10.24952/fitrah.v5i2.1893
}

$$
\begin{aligned}
& \text { ملخص } \\
& \text { إن صلاحية القرآن الكريم كمصدر رئيسي للإسلام لا يحدّها زمان و لا مكان. و تلك }
\end{aligned}
$$

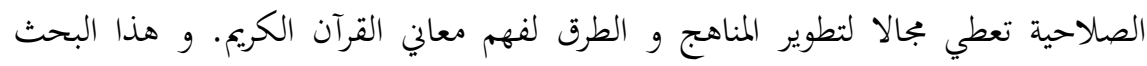

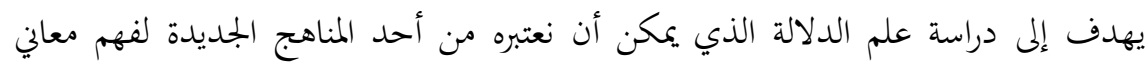

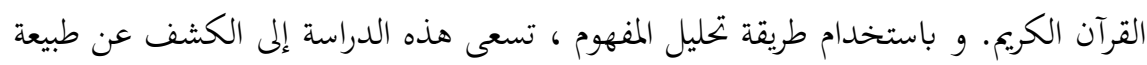

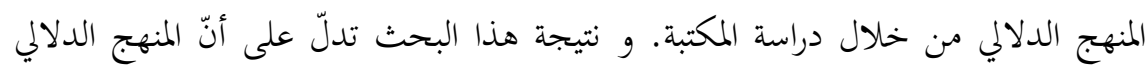

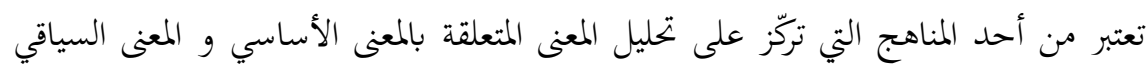

$$
\begin{aligned}
& \text { الذي يظهر عن طريقة "سنكرونيك" و "دياكرونيك". } \\
& \text { الكلمات الرئيسية: علم الدلالة ، دراسة القرآن ، الدراسات الإسلامية }
\end{aligned}
$$

\begin{abstract}
Abstrak
Sebagai sumber utama ajaran Islam, Alqur'an dituntut untuk selalu menampilkan relevansinya tanpa mengenal batasan ruang dan waktu. Tuntutan relevansi tersebut memberikan ruang bagi berkembangnya metode dan pendekatan dalam rangka memahami pokok kandungan Alqur'an. Penelitian ini dimaksudkan untuk mengkaji seluk beluk pendekatan semantik sebagai salah satu pendekatan yang relatif baru dalam diskursus kajian Alqur'an. Dilakukan dengan menggunakan metode analisis isi, penelitian ini berusaha mengungkapkan hakikat pendekatan semantik melalui penelaahan literatur. Hasil penelitian menunjukkan bahwa pendekatan semantik merupakan suatu pendekatan dalam pengkajian Alqur'an yang memfokuskan pada analisis makna yang berkaitan dengan makna dasar dan makna relasional yang ditemukan dengan metode sinkronik dan diakronik.
\end{abstract}

Kata Kunci : Semantik, Kajian Alqur'an, Studi Islam. 
FITRAH Jurnal Kajian Ilmu-ilmu Keislaman

Vol. 05 No. 2 Desember 2019

\section{INTRODUCTION}

Islam is believed to be one of the celestial religions, namely religions originating from God and conveyed through revelation to the prophet Muhammad, ${ }^{1}$ and is the last celestial religion brought and conveyed by the Prophet Muhammad. As one of the celestial religions, Islamic teachings are a revelation of Allah SWT that covers all aspects of human life. The revelations delivered to His Messenger Muhammad were the main points of Islamic teachings which were collected and written and called the Qur'an. Therefore the Qur'an is believed by all Muslims to be the main source of Islamic teachings.

Muslims believe that the Qur'an contains all aspects of human life because the Qur'an was revealed as a mercy for all nature (rahmatan lil 'alamin) and will remain relevant whenever and wherever (shalih li kulli zaman wa makan). The status of the Qur'an as the main source of Islamic teachings is the reason why the Qur'an is believed and must remain relevant throughout the ages without limitation of space and time. ${ }^{2}$ If the Qur' an has limited space and time, there will be many problems that appear later that are not accommodated clearly in the Qur'an discussion. As a result, the Qur'an will lose its relevance in human life that continues to grow, and then its existence will slowly erode and become an obsolete book. The Qur'an, which is not limited by time and space, is still able to answer new problems as a consequence of the development of the times. Therefore Subhi Soleh said that the Qur'an has the nature of syumul, which includes all aspects of life. ${ }^{3}$ The emergence of these new problems indirectly also affects the development of patterns of understanding or interpretation of the Qur'an as the main source of Islamic teachings.

Truth from the perspective of the Qur'an is an absolute justification that comes directly from Allah. It can be proven through two things, first, that the Qur'an comes from Allah, who created everything. Therefore the Qur'an has been designed according to human needs and abilities. Secondly, the Qur'an is a unified whole between one verse and the others so that humans will not be able to make their equivalents. ${ }^{4}$

\footnotetext{
2012), hlm. 44.

2 Yayan Rahtikawati dan Dadan Rusmana, Metodologi Tafsir Al Qur'an: Strukturalisme, Semantik, Semiotik dan Hermeneutik (Bandung: Pustaka Setia, 2013), hlm. 8-9.

${ }^{3}$ Arham Junaidi Firman dan Dkk, Studi Al-Qur'an (Teori dan Aplikasinya dalam Penafsiran

Ayat Pendidikan) (Yogyakarta: Diandra Kreatif, 2018), hlm. 132, https://books.google.co.id/books?id=EGx8DwAAQBAJ.

4 Abdul Hamid M.A Lc, Pengantar Studi Al-Qur'an (Jakarta: PT Fajar Interprama, 2016), hlm. 3, https://books.google.co.id/books?id=EstADwAAQBAJ.
}

${ }^{1}$ Muhaimin dan Dkk, Studi Islam: Dalam Ragam Dimensi dan Pendekatan (Jakarta: Kencana, 
Theologically-normatively, the truth of the Qur'an is absolute because it comes from Allah. However, when the truth transferred to human thought, the truth will change to a relative. Therefore even though the Qur'an is only one, understanding of it experiences diversity even there is not a bit of controversy and contradiction. ${ }^{5}$ This difference in understanding is due to the number of words, sentence structure, and systematics that tend to cause debate. Part of it caused by Allah choosing words that have more than one meaning. In part, this is because Allah's explanation is vague and requires expertise to understand it, and some verses contain complex problems with a dense language structure. ${ }^{6}$

In the modern era accompanied by the development of various branches of science, including linguistics, the study of the Qur'an from the aspect of language also develops. So in this modern era comes a new approach known as the semantic approach as an approach in studying the Qur'an. The Qur'an is revealed and conveyed to humans in clear and non-mysterious language so that they can understand and comprehend what is in it. Allah revealed the revelation to the Prophet Muhammad following the understanding of the instrument that is owned by the recipient of the revelation. Therefore, the first step taken is to change or convey the revelation in a form that can be understood by human knowledge. The perfection of human thought can be achieved through language - as Muhammad Shahrur argues - so that it has two consequences. First, the manifestation of the Qur'an in human language, and second, the Qur'an must have a special character; namely, its content is absolute, and its understanding is relative. This character is called the absolute form of linguistics, which is in the form of text, while its understanding is relative. ${ }^{7}$

The character of understanding which is always relative indicates that there is no final interpretation of a text, it can always develop. The Qur'an, as a language text, can be grasped and given meaning by the different levels of knowledge, reasoning power, and human experience. Understanding the Qur'an is often faced with semantic problems, a problem involving differences in understanding the meaning of words, which often leads to differences of opinion and interpretation. Efforts to comprehend conceptually the terms contained in the Qur'an comprehensively by analyzing the meaning of this are the urgency of

\footnotetext{
${ }^{5}$ Ahmad Izzan, Metodologi Ilmu Tafsir (Bandung: Tafakur, 2008), hlm. 49.

${ }^{6}$ Nadirsyah Hosen, Tafsir Al-Quran di Medsos: Mengkaji Makna dan Rahasia Ayat Suci pada Era Media Sosial (REPUBLISH) (Yogyakarta: Bentang Pustaka, 2019), hlm. 6, https://books.google.co.id/books?id=ieivDwAAQBAJ.

${ }^{7}$ Sugeng Sugiono, Lisan dan Kalam: Kajian Semantik Al-Qur'an (Yogyakarta: Sunan Kalijaga Press, 2009), hlm. 54.
} 
the semantic approach in the study of the Qur'an. Therefore, it is necessary to have a deep study of the semantic approach as one of the approaches in the study of the Qur'an.

\section{METHODS}

This type of research is library research, namely research that uses books as the main source of data. ${ }^{8}$ The data collection method uses the documentation method. The analysis of this research uses the content analysis method, which is an effort made to see and analyze the conceptual framework of the semantic approach and its application in scientific studies.

The content analysis method is a scientific analysis that emphasizes content or messages carried out objectively and systematically. Berelson emphasized that content analysis is a research technique for obtaining objective, systematic, and qualitative information about communication content. ${ }^{9}$ This method is expected to be able to produce a deep and objective understanding, especially about the concept of the semantic approach and its contribution to Islamic studies conducted by studying the meaning of words in the Qur'an.

\section{RESULT AND DISCUSSION \\ Definition of Semantic Approach}

Semantic words come from English. These words are the noun form of the Greek word sema, which means a sign or symbol, and the form of the verb smaino or semeion, which means to mark. The relationship between the sign or symbol with meaning, in this case, is something related to linguistics. De Saussure, as quoted by Abdul Chaer, mentioned the characteristics of the linguistic sign, namely: first, the component that replaces the tangible sound of language; and second, the meaning of the first component. ${ }^{10}$ Thus, semantics is something that symbolizes the purpose of a word or utterance, which is called the meaning.

Furthermore, the notion of meaning can be broadly divided into two senses, namely understanding the everyday meaning and understanding the meaning of the term. In everyday understanding, meaning be interpreted and aligned with words of ideas, concepts, messages, information, intentions, contents, and thoughts. While the meaning in terms is the relationship between

\footnotetext{
8 Sutrisno Hadi, Metodologi research (Yogyakarta: Andi Offset, 1990), hlm. 9.

${ }^{9}$ Prof Dr A. Muri Yusuf M.Pd, Metode Penelitian Kuantitatif, Kualitatif E Penelitian Gabungan (Jakarta: Prenada Media, 2016), hlm. 441-442.

${ }^{10}$ Abdul Chaer, Pengantar semantik bahasa Indonesia (Jakarta: Rineka Cipta, 2009), hlm. 2.
} 
language and the outside world that has been mutually agreed upon by the language users so they can understand each other. Aminuddin mentioned three main postulations about meaning. 1) Meaning is the result of the relationship between humans and the outside world. 2) The determination of the relationship occurs because of the agreement of the users. 3) Use the embodiment of meaning to convey information so that it can be mutually understood. This third point requires the existence of a convention or agreement and the similarity of views between the transmitter and receiver in the relationship of words and reality. ${ }^{11}$

The meaning is often related to communication. In communication, generally, the means used is language. That is, in the communication process, someone conveys ideas or anything to others using language. In the process, the transfer of meaning between the communicating people has occurred unconsciously. In this case, the meaning is very closely related and depends on several things, namely the user either the sender or receiver, how to use and the conditions when the language is expressed. Therefore, a word can have different meanings, depending on the person who uses the word. A word can also have a different meaning due to different situations and conditions. ${ }^{12}$ So, the meaning is the link that exists between the elements of language itself. Studying or giving meaning to a word is a process of understanding the study of the word concerning the relations of meaning that make the word different from other words. ${ }^{13}$

History has recorded that Arabic has always undergone changes and developments. These changes and developments occur in various aspects, including semantics, grammar, writing, and other aspects of language. In the semantic aspect, there are many changes in meaning which are both narrow and widespread. Changes in meaning are influenced by changes in social, psychological, and linguistic aspects. ${ }^{14}$

As mentioned above that semantics is a part of linguistic study that can be applied in all languages. So Arabic, which is the language used in the Qur'an, can also be studied in its semantic aspects. Semantics on the study of the Qur'an is an approach that became known and popular after an Orientalist named Toshihiko

${ }^{11}$ Aminuddin, Semantik: Pengantar Studi Tentang Makna (Bandung: Sinar Baru, 1988), hlm. 50-53.

${ }^{12}$ Rahtikawati dan Rusmana, Metodologi Tafsir Al Qur'an: Strukturalisme, Semantik, Semiotik dan Hermeneutik, hlm. 223.

${ }^{13}$ T. Fatimah Djajasudarma, Semantik I: Pengantar ke Arah Ilmu Makna (Bandung: PT. Refika Aditama, 1999), hlm. 5.

14 Yayan Nurbayan, Keindahan Gaya Bahasa Kinayah dalam Al Qur'an (Bandung: Royyan Press, 2016), hlm. 8, https://books.google.co.id/books?id=c9e8DwAAQBAJ. 
Izutsu wrote three books that specifically discuss the semantic study of the Qur'an. However, semantic studies of the language of the Qur'an began long before the advent of Izutsu, not even far from the period of the revelation of the Qur'an. However, scientifically and systematically, semantic studies of the language of the Qur'an have indeed begun to gain popularity since Izutsu elaborated it.

According to Izutsu, semantics is a science that deals with the phenomenon of meaning in a broader sense of the word. Semantics is an analytical study of the key terms of a language or society that uses that language. Not only as a means of speaking and thinking but, more importantly, is the conceptualization and interpretation of the world that surrounds it. ${ }^{15}$ In Izutsu's opinion, it can In that semantic study is an attempt to find a concept about something that is comprehensively obtained. Izutsu also emphasized that the application of semantic analysis requires cross-disciplinary studies, including linguistics, sociology, anthropology, philosophy, psychology, history, and other sciences. In the semantic study of the Qur'an, analysis of the meaning contained in a word in the Qur'an also requires a review of the historical scope of where and when the Qur'an was revealed. In this case, one of them is the context of the Arab community at that time and the pattern of the use of the Arabic language that became the language of the Qur'an.

Thus, the achievement of meaning to be discovered through semantic analysis is not only related to the elements of a sentence, the correlation between sentences, or related to figurative expansion in the meaning of the grammatical form and style of the Qur'anic text. Semantic analysis of the language of the Qur'an has a purpose more than just grammatical aspects, which includes the "way of life" of the Qur'an. The worldview that encompasses the ideas and worldview described by the Qur'an can be explored by revealing implicit significance. Semantic analysis of the language of the Qur'an is carried out to try to uncover what is behind the language, and even that is unspeakable. ${ }^{16}$

The semantic approach used in the Qur'anic interpretation discourse began after the Qur'an was codified. This period is commonly known as the classical period, where the use of semantic methods appears in the form of a prototype that continues to grow. From the systematic and scientific side, the use of semantic approaches to interpreting the Qur'an has not yet been fully formed

15 Toshihiko Izutsu, Relasi Tuhan dan Manusia Pendekatan Semantik Terhadap Alqur'an, terj. Agus Fahri Husein (Yogyakarta: Tiara Wacana, 1997), hlm. 2.

${ }^{16}$ Rahtikawati dan Rusmana, Metodologi Tafsir Al Qur'an: Strukturalisme, Semantik, Semiotik dan Hermeneutik, hlm. 234-244. 
as an approach in understanding the Qur'an. But in practice, the interpretation procedures used in interpreting a word in the Qur'an can be categorized as procedures and ways of working semantically. It is very reasonable because, at that time, the science of linguistics or balaghoh had not yet developed. ${ }^{17}$

The Muslim scholar who first used this semantic approach was Mujahid ibn Jabbar. From this figure, the embryo of interpreting Qur'anic verses using a semantic approach began to appear. It can be found in the interpretation of the word tsamar ( meaning that is generally understood as "fruit," but Mujahid defines it as "gold and silver," which indicates a wealth. It is the result of considering the importance of context and locality so that he feels the need to divert the meaning of the vocabulary from the original lexical meaning to the meaning developed from a context. ${ }^{18}$

Ibn Juraij also performs the same pattern of interpreting the Qur'an. The method used by Ibn Juraij is to distinguish between the original and the functional meaning of a word or sentence. Functional meaning is the meaning that can change according to the context of the verse being interpreted. It can be seen from Ibn Juraij's interpretation of Q.S. Al-Hajj verse 5, in the word hamidatan (هَامِدَةً). The default meaning of the word hamidatan (هَامِدَة) is “dry,” but Ibn Juraij gives it the meaning of "earth without a crop." Ibn Juraij believes that the context of a verse in the Qur'an has a very important role in understanding the text in the Qur'an. ${ }^{19}$

The use of semantics in the interpretation of the Qur'an in the classical era beyond what Mujahid and Ibn Juraij did begin to appear since the time of Muqatil ibn Sulayman. He asserted that every word contained in the Qur'an has definitive meanings and alternative meanings that can be numerous. He gives an example of the meaning of the word maut (مَوْت) in Q.S. Az-Zumar verse 30. According to him, the definitive meaning of the word maut (مَوْتو) is "dead." But it has at least four alternative meanings namely; drops that have not been turned on, human beings who have mistaken beliefs, barren land, and lost spirits. The various possibilities that arise from a word in the Qur'an are the main

\footnotetext{
17 Fauzan Azima, “Semantik Al-Qur'an (Sebuah Metode Penafsiran)," TAJDID: Jurnal Pemikiran Keislaman Dan Kemanusiaan 1, no. 1 (2017): 45-73, http://ejournal.iaimbima.ac.id/index.php/tajdid/article/view/3.

${ }_{18}$ M. Nur Kholis Setiawan, Al-Qur'an Kitab Sastra Terbesar (Yogyakarta: eLSAQ Press, 2006), hlm. 138.

${ }^{19}$ Setiawan, hlm. 144.
} 
requirements for understanding the Qur'an. Awareness of the various dimensions of the Qur'an is an absolute requirement for the process of mastering and understanding the Qur'an. ${ }^{20}$

Starting with this Muqatil ibn Sulayman, awareness of the semantic approach to understanding or interpreting the Qur'an continuesly. Many Muslim scholars in the field of Quranic interpretation began to follow the Muqatil, such as Aaron Ibn Musa, Yahya ibn Salam, al-Jahiz, Ibn Qutaibah, and al-Qodir alJurjany. In terms of interpretation, they underline the context as a dimension that must be understood in determining the meaning of words in the Qur'an. Al-Jahiz even provides his terms related to the relationship between one word with another word that can influence the meaning in the Qur'an with the term "semantic space." 21

The development of the Qur'anic interpretation with semantic style continues into the contemporary period. In this contemporary period, balaghoh as a linguistic discipline which more specifically also covers the science of badi' and ma'ani sciences began to develop. Tafsir, with a literary approach, is a product of the development of balaghoh, which is generally spearheaded by Amin al-Khully, who emphasizes the microstructural aspects of the meaning of the verse. Besides, the interpretation also appears with the linguistic-hermeneutic method which complements the interpretation methods with the language or linguistic approach. As a result, the semantic approach is only used as an aid in interpretation, not as a basic method in the process of interpretation. ${ }^{22}$

The most prominent figure in the semantic approach in the contemporary era is Tohishiko Izutsu. He is an orientalist who has a concern for the study of the meanings of keywords in the Qur'an. Through his works, he describes the application of the semantic approach to understanding key concepts in the Qur'an. Perhaps Izutsu is also the pioneer of the various applications of the semantic approach undertaken by later scholars who pursue the field of Ulumul Quran. So it's not surprising if we talk and study the semantics of the Qur'an in the current era, the name Izutsu is always a reference.

\section{Scope of Semantic Studies}

Broadly speaking, Moh. Matsna states that the scope of semantic studies revolves around at least three things. First, lafadz and the meaning and symbolic relationship between the two, such as social reflection, psychological, and

\footnotetext{
${ }^{20}$ Setiawan, hlm. 170.

${ }^{21}$ Setiawan, hlm. 177.

${ }^{22}$ Azima, "Semantik Al-Qur'an (Sebuah Metode Penafsiran)," hlm. 57.
} 
thought. Second, the development of meaning: causes and rules, and contextual and situational relationships in life, science, and art. Third, Majaz follows its semantic application and stylistic relationship. ${ }^{23}$

According to Izutsu, the words or concepts in the Qur'an are not simple; their respective positions separate from each other but highly interdependent and produce concrete meaning precisely from the whole system of relations. Words form groups that vary, large and small, and relate to one another. It ultimately results in an overall, very complex, and complicated order as a conceptual composite framework. Identifying the comprehensive meaning of one word contained in the Qur'an and the derivation of the word to find a particular concept as a view of the Qur'ani world is not an easy task. The reason is an identification of meaning is not enough to be done simply by using language dictionaries to look at the etymological meaning of words. But also an in-depth study of the historicity of word usage before being used in the Qur'an and changes in the concept of its meaning after the word is used in the Qur'an. Besides, the sociology and anthropology aspects are also a field or discipline that must be understood in depth.

The use of a word in the Qur' an that forms the conceptual meaning of the whole world view of the Qur'an is a form of a symbol that must be understood. The Qur'anic verse is a sentence that formed from a collection of words, where each word of verse has its meaning. To be able to understand the meaning or symbols contained in verse, then one of the prerequisites that must be met is the mastery of linguistics, including semantics. In the language, the Qur'an shows a great literary form, so that in addition to the content of the Qur'an, the beauty aspects of the language of the Qur'an are also recognized as a miracle. ${ }^{24}$

In language theory, in general, language should be an organism that can live, grow, develop, change, and even die. Similarly, the meaning is always inherent in a word or language. Meaning as part of a linguistic discipline or language, can also experience dynamic developments, shifts, and even change. Factors that can cause changes in meaning can be of various types including linguistic factors, historical factors, social factors, psychological factors and the influence of foreign languages..$^{25}$

${ }^{23}$ Moh. Matsna, Pengembangan Evaluasi dan Tes Baahasa Arab (Tangerang: Alkitabah, 2012), hlm. 4.

${ }^{24}$ Sukron Kamil, Teori Kritik Sastra Arab: Klasik dan Modern (Jakarta: PT Raja Grafindo Persada, 2012), hlm. 144.

${ }^{25}$ Rahtikawati dan Rusmana, Metodologi Tafsir Al Qur'an: Strukturalisme, Semantik, Semiotik dan Hermeneutik, hlm. 228-229. 
The nature of meaning is different from lafadz. The scope of meaning is so broad, flexible, and unlimited, while lafadz is relatively limited and easily limited. Therefore variations and ikhtilaf are far more extensive and broader. In general, the words contained in the Qur'an have a variety of meanings that can be used according to the sentence structure. A word in the Qur'an does not always only have a lexical meaning or the original meaning contained by the word. However, a word can experience an expansion of meaning that causes the word to have meaning that varies more than one meaning. The following things can cause some possible reasons why a word can experience an expansion of meaning; 1 ) because of the context of the language surrounding it; 2) because of differences in mufrod; 3) because of the majaz language style. The various meanings that can be understood and used from a word become a problem in understanding the Qur'an. It is the reason for the emergence of differences in understanding and interpretation of a verse. Muqatil ibn Sulaiman also confirms the many meanings of a word. He realized that every word in the Qur'an, besides having a definitive meaning, also had several other alternative meanings. ${ }^{26}$

In terms of the classification of meanings, Izutsu divides meaning into two categories, namely basic meanings and relational meanings. Izutsu said that the basic meaning is the meaning attached to the word itself, which always carries and attaches wherever the word placed and however it used. In the previous mention, the basic meaning is the same as the definitive meaning and also the original meaning. This basic meaning or definitive meaning is a meaning that never changes wherever the word is located and is the conceptual core of the word. In any system, the word still has the same meaning as long as it is still regarded as one word by the public. ${ }^{27}$

For example, the word "kitab," has a basic meaning both found in the Qur'an and found outside the Qur'an has the same meaning, which is the book. Another example is the word "yaum," which purely means "day" as its basic meaning. Both of these words have a definitive meaning that has become a joint consensus. In daily use, these two words always show what has been generally agreed about the meaning of the word. People naturally understand when both words are spoken by someone else. In this case, these two words occupy a "neutral" position according to the general understanding of the users of those words. So the basic meaning is a position of meaning that is commonly understood by its users. Both meanings will have different meanings if related to

26 Setiawan, Al-Qur'an Kitab Sastra Terbesar, hlm. 170.

${ }^{27}$ Izutsu, Relasi Tuhan dan Manusia Pendekatan Semantik Terhadap Alqur'an, hlm. 11. 
the context of the verse in the Qur'an so that the "neutral" position of the word can change with many variations.

What is meant by relational meaning is apart from the basic meaning, which shows something connotative. This meaning added to the existing meaning by putting the word in a special position in a special field, being in a different relationship with all the other important words in the system. ${ }^{28}$ Changes or extensions of meaning that occur from a word, in this case, are caused by its use in a particular verse context in the Qur'an. It makes the meaning contained in the word exceeds the basic meaning possessed.

To make it easier, let's take an example of the words that have been explained above about the basic meaning. The word "kitab" and the word "yaum" in a neutral position with the basic meaning means the book and the day. The two words will have meaning that is far different from the basic meaning as a result of its application in the context of certain verses in the Qur'an. The first word, "kitab," has connotations that go far beyond even the basic meaning. In the context of the Qur'an, the word "kitab" has extraordinary significance as a sign of a very special religious concept that is surrounded by the light of holiness. It seen from the fact that in the context of the Qur'an, the word "kitab" has a very close relationship with divine Revelation or quite diverse concepts that directly refer to the revelation of revelation..$^{29}$

Connotative meaning in the word "kitab" is not much different from the connotative meaning in the word "yaum." The content of connotative meaning in the word "kitab" is not much different from the connotative meaning which is owned in the word "yaum." Lexically, the word "yaum" has a definitive basic meaning with the day. Namely, ordinary days as always passed and also known by most humans. However, the use of the word "yaum" in a verse context in the Qur'an gives many changes to the concept of the meaning of the word "yaum." When applied in the context of the Qur'an, the word has connotations of meaning that are quite diverse as doomsday, judgment day, and others. ${ }^{30}$

In the semantic analysis, what is sought is not only the relation of words with other words but also the concrete meaning of relational. ${ }^{31}$ Semantic analysis wants to represent the importance of understanding the fragmented ideas of the

${ }^{28}$ Izutsu, hlm. 12.

${ }^{29}$ Izutsu, hlm. 11.

${ }^{30}$ Izutsu, hlm. 12-13.

${ }^{31}$ Masna Hikmawati, Perbedaan Qira'at dan Pemaknaan: Analisis Semantik-Gramatikal dalam Alquran (Jakarta: Youmg Progressive Muslim, 2017), hlm. 34-37, https://books.google.co.id/books?id=NbZEDwAAQBAJ. 
Qur'an to achieve its total idea (world view). The importance of finding comprehensive concepts in the Qur'an is a consequence and also a necessity as a form of manifesting the function of the Qur'an as guidance. The fact that Allah revealed the Qur'an for the benefit of humankind requires a proper understanding of the teachings contained therein. ${ }^{32}$

In the Qur'an, there are the main points of Islamic teachings that can be understood by humans through a deep and comprehensive study. The Qur'an also contains clarity about the perceptions and conceptions of society faced by the Qur'an that shape the world view of the Qur'an. The Qur'anic worldview formed from words that form a dense network system. Several important words determine the main pattern of the system. In the Qur'an, the words that are key to the formation of the world view of the Qur'an are the semantic fields in the conceptual network of the Qur'an. At least, according to Fazlur Rahman, there are eight major themes and points in the Qur'an, namely: 1) God; 2) humans as individual creatures; 3) humans as members of society; 4) the universe; 5) prophecy and revelation; 6) eschatology; 7) evil and evil; and 8) the birth of the Muslim community. ${ }^{33}$

Meanwhile, according to Izutsu, what he called the keywords, words that play a very decisive role in the preparation of the basic conceptual structure of the Qur'anic worldview are words such as the words of Allah, Islam, faith, infidels, prophets, raasul, jannah, nar, and so on. These words have an independent position, but they are related to one another and produce concrete meaning from the whole relationship. The whole system of relations is what is referred to as the world view system (weltanschauung), which is typical of the Qur'an.

In analyzing these keywords, Izutsu conducted a semantic analysis to find out the meaning of a word based on time. He then divided the analysis pattern into two, namely diachronic analysis and synchronous analysis. Both of these analyses are used to discover the historical aspects of a word, especially words that were used in pre-Islamic times and later became the language of the Qur'an. Historical review of these words includes the development of a word, its use before and after Islam, its use in a certain period, as well as the emergence of new words.

\footnotetext{
${ }^{32}$ Rahtikawati dan Rusmana, Metodologi Tafsir Al Qur'an: Strukturalisme, Semantik, Semiotik dan Hermeneutik, hlm. 244.

${ }^{33}$ Rahtikawati dan Rusmana, hlm. 245-246.
} 
In etymology, diachronic means a view of language, which, in principle, focuses on the element of time. Thus, diachronically, vocabulary is a collection of words, each of which grows and changes freely in its unique way. Some words in the group can stop growing in the sense of stopping their use by the community within a certain period. While other words can continue to be used for a long time. Once again, new words can make their debut at the arena at any given point in time and begin their history in that period. In other words, there is a vocabulary that goes along with the times forgotten and not used by the community so that the vocabulary is called dead or not growing. At other times, there is a new vocabulary included in the vocabulary and is used by the community at that time.

The vocabulary collected at one time forms a network and sentence patterns as a result of community culture. In this case, Izutsu refers to a surface. On such a surface and only on that surface, these words appear before us in the form of a complex network of concepts. So that the point of view that crosses the historical lines of these words enables us in this way to obtain a static word system, called synchronous. ${ }^{34}$

Vocabulary, in this particular sense, namely the static surface of words, is something artificial. It is a static condition that is artificially produced by a single blow in the historical flow of all the words in the language at a particular point in time. The resulting cross-sections give an impression to us as static, but it only seems that way. In other words, it is only static when viewed from a macroscopic perspective. Microscopically, these surfaces stimulate life and movement. ${ }^{35}$ This situation is very clear when language is in a critical and revolutionary period.

Historical semantics is not a mere historical tracing of individual words to see how they change in meaning because of the course of history. The real historical semantics only start when we examine the history of words based on the entire static system. if we compare two or more surfaces of one language, it will bring up different stages of history, separated from each other by time intervals. ${ }^{36}$ The interval can be long or short, depending on the purpose of our analysis. For example, even the language of the Qur'an itself can be considered as a historical process that lasted for more than twenty years with a unique period, the Mecca and Medina periods. The language at important points, then compares the two cross-sections between one and the other, if we aim to conduct a

\footnotetext{
${ }^{34}$ Izutsu, Relasi Tuhan dan Manusia Pendekatan Semantik Terhadap Alqur'an, hlm. 32.

${ }^{35}$ Izutsu, hlm. 33.

${ }^{36}$ Izutsu, hlm. 33.
} 
semantic study of the development of Islamic thought within the confines of the Qur'an. ${ }^{37}$

Then Izutsu made an effort to show this problem most simply and clearly possible by isolating three different semantic surfaces at the beginning of alQur'an's vocabulary history. First, before the fall of the Qur'an or the period of ignorance, the second period of the arrival of the Qur'an, and the last period after the arrival of the Qur'an. ${ }^{38}$

Thus, in the first stage of pre-Islamic times, we have three different word systems. 1) Pure Badwi vocabulary representing very ancient Arabic weltanschauung and very nomadic characters. 2) The vocabulary of the merchant group. 3) Judeo-Christian vocabulary, a system of religious terms used among Jews and Christians living in Arab lands. ${ }^{39}$ These three elements are important elements of pre-Islamic Arabic vocabulary.

\section{Application of Semantic Approaches in Islamic Studies}

In terms of its position in the study of the Qur'an, Qur'anic reviewers have varied opinions about semantics. Some of them consider that semantics is an approach that is part of the content analysis method. Others place it as an independent method. Some reviewers put it as part of the interpretation, and some others do not so clearly put a semantic position in the study of the Qur'an. In the interpretation of interpretation, semantics also can occupy various positions. Is it a part of lughowi's interpretation? Is it a part of maudhu's interpretation, or is it an independent method that can be used as a knife for analysis. ${ }^{40}$

Semantics, as a method or approach, has procedures or steps of use. The procedure is explained in the following steps :

1. Determine the words to be examined

The first step that must be done in the procedure of applying a semantic approach is to determine the words to be studied and the meanings and concepts contained therein. Then make the word as a focus word surrounded by keywords that influence the meaning of the word to form a concept in a semantic field. Focus words are keywords that specifically indicate and constrain relatively independent conceptual fields that differ in

${ }^{37}$ Izutsu, hlm. 34

${ }^{38}$ Izutsu, hlm. 35.

${ }^{39}$ Izutsu, hlm. 35.

${ }^{40}$ Rahtikawati dan Rusmana, Metodologi Tafsir Al Qur'an: Strukturalisme, Semantik, Semiotik dan Hermeneutik, hlm. 264-265. 
overall vocabulary and are the conceptual center of several specific keywords. Keywords are words that play a very decisive role in the preparation of the basic conceptual structure of the Qur'anic worldview. While the semantic field is a region or region formed by a variety of relationships between words in a language. ${ }^{41}$

2. Revealing the basic meaning and relational meaning

The next step is to determine the basic meaning and the relational meaning of a word. ${ }^{42}$ The basic meaning is known by using an Arabic dictionary that specifically discusses the words that are in the Qur'an. While the meaning of relational is known after the occurrence of syntagmatic relations between focus words with keywords in a semantic field. ${ }^{43}$

3. Perform synchronous and diachronic analysis

The next step after discovering the basic meaning and relational meaning are to reveal the historical meaning of the word or historical semantics. In tracking the history of the meaning of this word, there are two important terms in semantics, namely diachronic and synchronous. Diachronic is a view of language that focuses on the element of time. While synchronous is the perspective of the period in which a word is born and changes in meaning in line with the historical course of the use of the word in a user society to obtain a static meaning system. In tracking the history of words in the Qur'an, diachronically looks at the use of the word in the Arab community, both in the period before the Qur'an's descent, during the time of the Holy Prophet, in the period after the Prophet until the contemporary era to find out the importance of the word in the formation of the Qur'ani vision. Meanwhile, synchronously emphasizes the change in language and its meaning from the first time the word used until it becomes a separate concept in the Qur'an.

4. Reveal the concept or worldview of the Qur'an

The final step in applying the semantic approach in the study of the Qur'an is to reveal what concepts the Qur'an offers to its readers. Finally, the concept can be used as a guide by humans in everyday life following the rules of the Qur'an.

From the explanation of the above procedure, it can be seen that the semantics of the Qur'an aim to provide a new understanding of what is

\footnotetext{
${ }^{41}$ Izutsu, Relasi Tuhan dan Manusia Pendekatan Semantik Terhadap Alqur'an, hlm. 18-22.

${ }^{42}$ Izutsu, hlm. 12.

${ }^{43}$ Izutsu, hlm. 16.
} 
offered by the Qur'an. At first glance, it appears that the application of the semantic approach to its diachronic analysis of words in the Qur'an is similar to the double movement theory offered by Fazlur Rahman. The difference is that the semantic approach rests on the meaning of keywords only while the study offered by Fazlur Rahman does not.

As an example of applying a semantic approach to discovering the conceptual meaning of words in the Qur'an, several studies have been carried out. Various words are considered to tend as keywords have been assessed using this semantic approach. One of them certainly presented by Izutsu as the party who "introduced and popularized" the larval approach in the study of the Qur'an. The word used as an example by Izutsu is "kafara" (كَفَرَ). This word, Lexically and definitively, means "ungrateful." The word is generally understood as a form of attitude that shows a sense of ungratefulness or gratitude for good deeds or help shown by others. This word is the proper antonym for the word "syakara" (نَخَرَ), which means "grateful." The use of the word "kafara" (كَفَر) , as well as its meaning, is already in full effect, both in the vocabulary of Arab Muslims and non-Muslims. In fact, according to Izutsu, the use of this word has not changed much since pre-Islamic times to the present usage. The meaning of "kafara" (كَرَ) shows a behavior that is contrary to the behavior of being grateful. ${ }^{44}$

However, the use of the word "kafara" (كَفَ) in the context of the Qur'an causes a very significant change in meaning. According to Izutsu, in the context of the Qur'an, the word comes from pre-Islamic vocabulary and is placed in a semantic field. The phenomenon of the language of the Qur'an that occurs explains how the word "kafara" (كَفَ) experiences deviations and changes in conceptual meaning after being included in the context of the Qur'an. These changes occur little by little from the original meaning of "ungrateful," which then changes its meaning, which leads to the meaning of "unbelief" as a form of denial appropriate to the concept of faith. In this context, the word "kafara" (كَفَ) is no longer the opposite of the word or antonym of the word "syakara," but the word "kafara" (كَفَ) is more inclined towards and being the opposite of the word "amana" which means belief. ${ }^{45}$

${ }^{44}$ Izutsu, hlm. 14.

${ }^{45}$ Izutsu, hlm. 14-15. 
The conceptual change of meaning from the word "kafara" (كَفَ) illustrates a change that is quite obvious. The basic meaning contained in the word "kafara" (كَفَرَ) which has been understood and used by the general public in society is slowly undergoing a shift in meaning that is so contrasting. In the basic meaning contained in the word "kafara" (كَفَ), there is no link between the meaning of the word and the concept of faith. However, after the word has been entered in a special semantic field in the Qur'an, the word "kafara" (كَفَ) develops its meaning leading to a concept of faith. This new meaning, which is different from this basic meaning, is relational as a result of its use in the Qur'anic language.

Examples using other words in the application of this semantic approach are the words "ulu al-albab." Lexically the word has a basic meaning "people who have common sense knowledge and insight." When analyzed using diachronic analysis, the word "ulu al-albab" becomes an existing word and is used in preIslamic terms, which is sometimes used as a vocabulary in communication. It can be proven one of them in poetic sentences that use the "albab" vocabulary. Poetry was popular in pre-Islamic times as a place to express the use of a language or sentence. The word "ulu al-albab" is used to refer to a person's intelligence and knowledge that is so broad that they do not neglect their Lord. ${ }^{46}$

In the context of the Qur'an, these words are often closely related to other words such as Allah, the Qur'an, the universe, taqwa, qasas (stories), tadabbur, and others. Antonyms or opposite words of these words are generally the words "jahil," "sufaha," and "kusala," which generally shows stupidity and laziness. Meaning in the context of the Qur'an has several possibilities that are quite diverse and varied. In the present context, the word can be interpreted with the ability and quality possessed by someone. The attitude or quality consists of at least four qualities that are always inherent and difficult to be separated from the figure of "ulu al-albab," namely spirituality, morality, intellectuality, and professionalism. ${ }^{47}$

\section{CONCLUSION}

Semantics can be understood as a study of meaning. Semantics is a branch of linguistics that discusses the intricacies of language, both verbal and

${ }^{46}$ Eko Zulfikar, "MAKNA ŪLŪ AL-ALBĀB DALAM AL-QUR'AN: Analisis Semantik Toshihiko Izutsu," Jurnal THEOLOGIA 29, no. 1 (2018): hlm. 136, https://doi.org/10.21580/teo.2018.29.1.2273.

${ }^{47}$ Zulfikar, hlm. 136. 
written. In this context, semantics are used to analyze language in written form that is in the Qur'an. The semantic approach in Islamic studies is an approach or method used to analyze the meaning of a word in the Qur'an so that it found conceptually. Based on the object of study, the semantic approach can be categorized as part of a normative approach in the study of Islam because the object of study is the Qur'anic texts.

In terms of meaning analysis, this semantic approach to the Qur'an provides two patterns of analysis, namely synchronous and diachronic analysis. This analysis provides an opportunity for scholars to study the deeper meaning of the words in the Qur'an by looking at the history and development of word usage over time. There are four procedures for applying this approach. 1) choosing keywords that will be the focus of the analysis. 2) disclosure of basic meanings and relational meanings. 3) perform synchronous and diachronic analysis. 4) revealing the conceptual meaning and view of the Qur'an world. 


\section{REFERENCES}

Aminuddin. Semantik: Pengantar Studi Tentang Makna. Bandung: Sinar Baru, 1988.

Azima, Fauzan. "Semantik Al-Qur'an (Sebuah Metode Penafsiran)." TAJDID: Jurnal Pemikiran Keislaman Dan Kemanusiaan 1, no. 1 (2017): 45-73. http://ejournal.iaimbima.ac.id/index.php/tajdid/article/view/3.

Chaer, Abdul. Pengantar semantik bahasa Indonesia. Jakarta: Rineka Cipta, 2009.

Djajasudarma, T. Fatimah. Semantik I: Pengantar ke Arah Ilmu Makna. Bandung: PT. Refika Aditama, 1999.

Firman, Arham Junaidi, dan Dkk. Studi Al-Qur'an (Teori dan Aplikasinya dalam Penafsiran Ayat Pendidikan). Yogyakarta: Diandra Kreatif, 2018. https://books.google.co.id/books?id=EGx8DwAAQBAJ.

Hadi, Sutrisno. Metodologi research. Yogyakarta: Andi Offset, 1990.

Hikmawati, Masna. Perbedaan Qira'at dan Pemaknaan: Analisis Semantik-Gramatikal dalam Alquran. Jakarta: Youmg Progressive Muslim, 2017. https://books.google.co.id/books?id=NbZEDwAAQBAJ.

Hosen, Nadirsyah. Tafsir Al-Quran di Medsos: Mengkaji Makna dan Rahasia Ayat Suci pada Era Media Sosial (REPUBLISH). Yogyakarta: Bentang Pustaka, 2019. https://books.google.co.id/books?id=ieivDwAAQBAJ.

Izutsu, Toshihiko. Relasi Tuhan dan Manusia Pendekatan Semantik Terhadap Alqur'an. terj. Agus Fahri Husein. Yogyakarta: Tiara Wacana, 1997.

Izzan, Ahmad. Metodologi Ilmu Tafsir. Bandung: Tafakur, 2008.

Kamil, Sukron. Teori Kritik Sastra Arab: Klasik dan Modern. Jakarta: PT Raja Grafindo Persada, 2012.

M.A, Abdul Hamid, Lc. Pengantar Studi Al-Qur'an. Jakarta: PT Fajar Interprama, 2016. https://books.google.co.id/books?id=EstADwAAQBAJ.

Matsna, Moh. Pengembangan Evaluasi dan Tes Baahasa Arab. Tangerang: Alkitabah, 2012.

M.Pd, Prof Dr A. Muri Yusuf. Metode Penelitian Kuantitatif, Kualitatif \& Penelitian Gabungan. Jakarta: Prenada Media, 2016. 
Muhaimin, dan Dkk. Studi Islam: Dalam Ragam Dimensi dan Pendekatan. Jakarta: Kencana, 2012.

Nurbayan, Yayan. Keindahan Gaya Bahasa Kinayah dalam Al Qur'an. Bandung: Royyan Press, 2016. https://books.google.co.id/books?id=c9e8DwAAQBAJ.

Rahtikawati, Yayan, dan Dadan Rusmana. Metodologi Tafsir Al Qur'an: Strukturalisme, Semantik, Semiotik dan Hermeneutik. Bandung: Pustaka Setia, 2013.

Setiawan, M. Nur Kholis. Al-Qur'an Kitab Sastra Terbesar. Yogyakarta: eLSAQ Press, 2006.

Sugiono, Sugeng. Lisan dan Kalam: Kajian Semantik Al-Qur'an. Yogyakarta: Sunan Kalijaga Press, 2009.

Zulfikar, Eko. "MAKNA ŪLŪ AL-ALBĀB DALAM AL-QUR'AN: Analisis Semantik Toshihiko Izutsu." Jurnal THEOLOGIA 29, no. 1 (2018): 109-40. https://doi.org/10.21580/teo.2018.29.1.2273. 